\title{
射流を含む水流の計算に就で
}

$$
\text { 本 }^{3} \text { 留 仁 }
$$

\section{On the calculation of flow containing jet.}

Masashi Honma, Member

\section{- Abstract}

When we calculate the equation of flow by a numerical method, the caleulation must be $\mathrm{advanced}$ in upward direction from the lower end of flow in the case of prdinary flow; that is when the flow is lower than the wave in the channel. While in the case of jet flow, that is when the flow is faster than the wave, the calculation must be advanced in downward direction.

In some problems it is possible for the state of flow to change from ordinary to jet in the course of running, and then the initial point of calculation can not be given artificially.

The author explains when such cases will happen and how the calculation is to be done in such cases.

河川の堤防の高さをきめる場合を初め，色ぬな水路の 大きさを設計する際には，ある區間每に一樣な流れと假

・定して計算して行くのが普通である。郎ら斷面の變化な ぞによる影響は多くの場合に局部的である加ら，以上の 上.5な考へ方でも全體的な設訐は出來る。然し利根川の 水害の例を見ると，極めて一局部に於ける Over flow

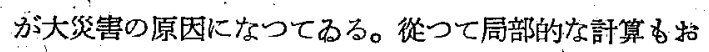
ろそかにする事性出來ないのである。特に流れの中に射 流部の現れる場合にはその訐算上に特別な注意が必要で ある。

水面を傳わる波（長波）上りも速い、流速を持つた流れ 学射流 (Jet flow) と名付けて, 波速以下の流れを常流 (Ordinary flow) と呼んで區別する。從つて水梁 $h$, 速度 $v$ の水流に於て Froude 數を $\frac{v}{\sqrt{g h}}$ と取ると, 射 流では Froude 數が1より大きく、常流では之が 1 より 小さい事になる。 Dam 名 Overflow する水保頂上厄 Froude 數が 1 になり，その上下で夫ふに常流及び射流 になるので劣る。, 一樣な流れで, 岁る限界の勾配

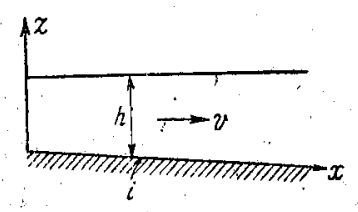

第 1 圆
を境として，之上り急性勾 配では射流, 之上り䌊かな 勾配では常流となるのです るが，この限界の勾配は水 路面の粗さK關係し；竇驗 窒內の水路などでは $\frac{1}{800}$ 前
後，實際の河川では ${ }_{150}^{1} \sim \frac{1}{200}$ 程度でつて. 我國の河 川には本地部に出てからす同ての程度の勾配学持つてる るものがかなりる。

一樣な底勾配 $i$ の Open channel の定常的な流水の 平均流速を $v$ ，水深安 $h$ とすると，鍇直方向の加速度 を無視すれは，水區の强さは

$$
p=p g z \text { + const. }
$$

となるから，運動方程式は次の形で與へられる。

$$
\underbrace{-i+\frac{d h}{d x}}_{\begin{array}{c}
\text { Pot. } \\
\text { Energy }
\end{array}}+\alpha \frac{d}{\underbrace{}_{\text {Kinetic }}(x)\left(\frac{u^{2}}{2 g}\right)}+\underbrace{f_{1^{2}} v^{2}=0}_{\begin{array}{c}
\text { Loss of } \\
\text { Energy }
\end{array}}
$$

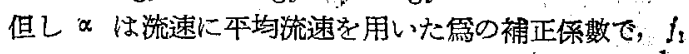
は Chezy 型の抵抗弪式を探用する事にすれば $f_{1}=\frac{1}{C^{2} R}$ ( R は Hydraulic mean depth) となるすのである。 この中の $C$ は粗さと Reynolds 数とに關係するものた 岁るが, 計算に必要な程度の概略值は何時ても求められ る。

運續方程式は流量を $Q$ とした時に

$$
v \doteq f(Q, b, h)
$$

で與究られる。但し水路の斷面形を幅の廣い,短形々假定

して, その幅を $b$ と書く。

例え酒幅の一橉な水路で

$$
b=\text { const. }
$$

幅の戀化する氷路で

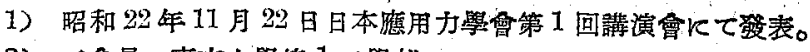

2) 正會員 東栄大學第 1 工學部 


$$
\boldsymbol{b}=\boldsymbol{b}(x) \text { (given), } \quad v=\frac{\dot{Q}}{\boldsymbol{b}(x) h(x)}
$$

貯水池の餘水吐水路, 或は道路の側溝の樣に，流れなが

ら㣴加ら一定の水の供給を受りてるる場合には

$$
Q=Q(x) \text { (givin), } \quad v=\frac{Q(x)}{b h(x)}
$$

但しとの場合にる， $\boldsymbol{0}$ や $Q$ の變化は急激でないと假 定して和く。郎ち羭り愊が急に擴がれは优壁から流線が 隺れる事になり，又鉛值速度或分を無視した假定に反す

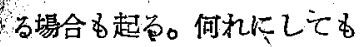

$$
\begin{aligned}
& d v \\
& \frac{d}{d x}\left(\frac{Q}{b}\right) \text { は計算出來量でるる。 }
\end{aligned}
$$

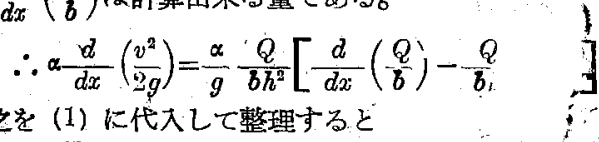

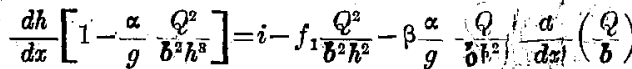

$Q=$ const. の時は $\beta=1, Q \neq$ const. 但し㭬加らの流入のある場合には，運動方程式の中に流 入する水が位置ェネルキだけを持つて入る事と假定する。 と, (1) 式には $-\frac{d Q}{d x} d x \times \frac{\alpha v^{2}}{2 g}$. 項が加はるから補正保 數防必要になる。

vを本均流速とすれば，Froude 數は $\frac{\sqrt{\alpha} v}{\sqrt{g h}}$ となつ $\tau$ ，射流と常流との限界水梁 $h_{c}$ は

$$
\begin{aligned}
& \frac{\sqrt{\alpha v}}{\sqrt{g h_{c}}}=1 . \quad \text { 即ち }=h_{c} \sqrt{\frac{\alpha Q^{2}}{g b^{2}}} \\
& \text { て與へられる。從つて (2) 加ら } \\
& \frac{d h}{d x}\left(1-\frac{h_{c}^{3}}{h^{3}}\right)=i-f_{1} \frac{Q^{2}}{b^{2} h^{2}}-\beta \frac{\alpha}{g} \frac{Q}{b h^{2}} \frac{d}{d x}\left(\frac{Q}{b}\right) \\
& \text { 或は } \frac{d h}{d x}=\frac{F_{2}(h, x)}{F_{1}(h, x)}
\end{aligned}
$$

之書加れ， $F_{1}(h, x)=0$ の根は $h=h_{c}$ でする。及 Chezy の公式 $v=C \sqrt{ } \bar{h}$ を满足する $h$ の值を $h_{0}$ で表はせば $F_{2}(h, x)=i\left(1-\frac{h_{0}{ }^{3}}{h^{3}}\right)-\beta \frac{\alpha}{g} \frac{Q}{b} h^{2} \frac{d}{d x}\left(\frac{Q}{b}\right)$ そこで $F_{\mathrm{g}}(h, x)=0$ を滿足する $h$ の値を

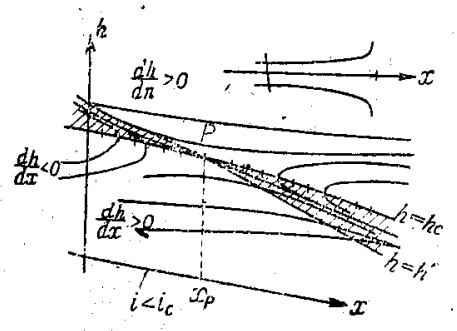

事 2 圈 $Q=$ const., $b=$ const. 時は $h$ $=h_{0}$ であつて, 畒通の Backwater の厹式 になる。

(3) 武表與方 られた境界條件 の下に數値䅣分
と行光ば，水面の Profil 为求められる。先づとの Profil の性質を調べる骨に， $h=h_{c}$ 及び $h=h^{\prime}$ の雨曲線を圆 k書き込さと，底勾配の比較的緩い場合には，幅力下流 の方に向つて摭加る水路や，橫加らの流入の方る水路に 對しては，一般にこの兩曲線が一點 $P$ た艾わつてるる。 そして水面の Profil は $h=h^{\prime}$ に交わる點には底に平行， $h=h_{c}$ に㚆はる點では鉛值になる。

佮この Profil 㓔流の時は， $x \rightarrow \infty$ に於て莫近的に $h=h$ に近付き，常流の時には $x=-\infty$ に於て濑近的に $h=h^{\prime}$ に近付く。この事は二種類の流饥の性質上の大き な違いを示するのである。即ら，

1. Jet flow で住或る地點で水梁の變化为起ると， その䪹化は下流側には無限に傳はるが，上流側に は或る籁園しか得はらない。，

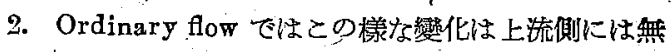
限に僧はるが，下流側には傳はらない。

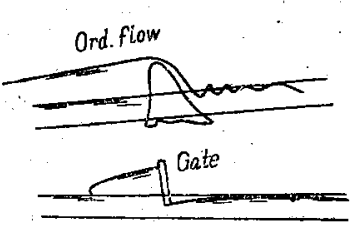

圆3はその例を示してる る。

水路を設許して，與へら れた流量に對する Porfi! を計算する際には，既に述 べた樣に，(3) 式を與へら れた境界條件 $h=h_{1}$ at $x$ $=x_{1}$ から出發して数值皘分して行くのでするが，上K 远べた性質を知つて訐算定行はないと，實除には起り得 なし、狀態を計算すると言ふ場合が起り滕ちでるる。

一般に言つて Ordinary f. ならば下流端の條件加ら 出發して上流に问つて計算し，Jet. f. ならば上流端の 條件から出登して下流に向つて訐算する事が必要であつ て，反對方向に計算すると賽除には control 出來ない狀 態を訐算するる結果になる。何特別の注意を必要とするの は Profil が兩線の交點 $P$ ，起通り，流れが Ordinary から染中て Jet に變り，Hydraulic jump によつて再 び Ordinary，に㞔る場合である。之は Ordinary f.の 水流に對して下流端での條件 $h=h_{1}$ が或る限界値以下に なつた時に起るので名つてこの時は下流端てどの樣に $h_{1}$ の條件を變えても， $h_{1}$ が限界値の範圍內にある限り Profil は途中で Hydraulic jump 方現はれ，それか ら上の形は境界條件に無關俰に unique でする。郎らこ の樣な籍園內では我々は水面の Profil を control ‘

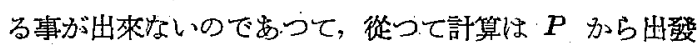
して上下流に向つて進めなければならない。P、に於ける 


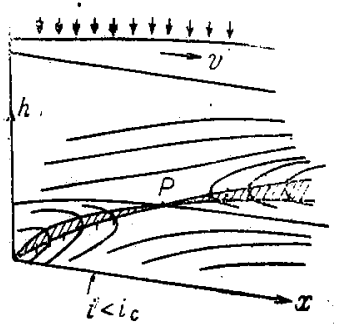

第 4 圆 $\hbar$ 及び $x$ の值は直らに阡 算出來るから，之に對して

$$
\left[\begin{array}{r}
d h \\
-d x
\end{array}\right] p=\lim
$$$$
\frac{\frac{d d}{d x} F_{2}\left(h_{1} x\right)}{\frac{d}{d h} F_{1}\left(h_{1} x\right)}
$$

但し $h=f(x)$

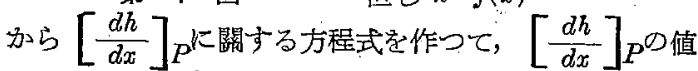
を求め，之昰利用して計算を淮めればないのである。

Dam の Orerflow の場合には，遠し力の影響が入つ $\tau$ ，(1) 式中の $-i+\frac{d h}{d x}$ の項 が䟣正されれば ならない。假り に遠心力の爲に

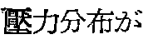

$$
p=\rho g \zeta-\alpha \boldsymbol{\zeta}^{*}
$$

厄表わされるす のと考へると，

\section{Hydraulic}

gradient $=$$$
=\frac{d}{d x}\left[z+(h-\zeta)+\frac{p}{\rho g}\right]
$$
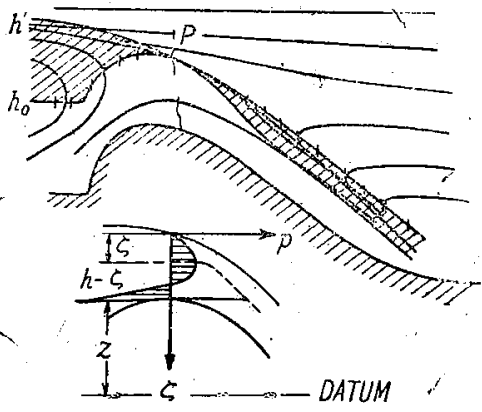

第 5 圆

そこで $a \zeta^{n}$ の鉛值斷面を通じての本均值を求めると

$$
\frac{1}{h} \int_{0}^{h} a \zeta^{n} d \zeta=\frac{a}{n+1} h^{n}
$$

從つて Hydraulic gradient $i-\frac{d h}{d x}$ の代りに 次の形に゙なる

$$
i-\frac{d h}{d x}+b h^{\mathrm{n}-1} \frac{d h}{d x}
$$

從つてとの場合は

$$
F_{1}(h, x)=1-b h^{n-1}-\frac{h_{c}^{-3}}{h^{3}} .
$$

となる。そこで $F_{1}(h, x)=0$ の㮛は $h=h_{c}$ とは少し違つ た $h=h_{e}{ }^{\prime} に$ 床る。

この場合にも $h=h^{\prime}$ と $h=h_{c}^{\prime}$ の兩曲線は Dam の Crest の上で交はり，水面の Profil は境界條件が或る

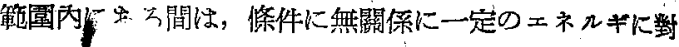
して得 にきまつてるる。而る一般に考へてるる

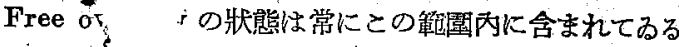
のである。算に若しこの Free overflow の Profil を計 算するのに，上流の方で水深と流速を與へると，之は全 エネルギを與へると共に流量す與へた專になつて，計算 される曲線は一般には $P$ を通る曲線とはならないのて ある。この事は流量測定暝で上流の方の水梁（實際は之 をニネルキの總和と見做す）さえ測えば，流量が一義的 にきめられる事からも確認出來る所で岁る。

そこで計算はやはり $P$ の位置から上下に向つて初め られるべきるのであつて，普通に Dam の流量を與へる 公式を導く際には，Pに於ける條件を最小土ネルキの 法則で代用してるるのである。

\section{'合併號についてのな知らせ}

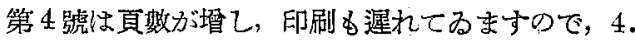
，5合件號と致します。第 6 號をる年內に刊行乙，第7 號より新らしい編集方法に依る會誌を發行致す豫定で to

新らしい編策方法並びに新執筆要項は別絓を御覽下 さい。 